\title{
Comparison of Cold Hardiness Evaluation of Woody Species by ELLT and TTCLT
}

\author{
Hui-qing Li, Qing-he Li, Lei Xing, Gao-jie Sun, and Xiu-lian Zhao \\ Research Institute of Forestry, Chinese Academy of Forestry, Beijing \\ 100091, China
}

Additional index words. cambium, electrolyte leakage, phloem, pith, TTC, xylem

\begin{abstract}
Cold hardiness evaluation is important for screening woody species in cold areas. We compared cold hardiness by estimating the $50 \%$ lethal temperature $\left(\mathrm{LT}_{50}\right)$ using electrolyte leakage test $\left(\right.$ ELLT $\left._{50}\right)$ and triphenyltetrazolium chloride test (TTCLT 50 ) for 26 woody species in the Bashang region of China. One-year-old shoots were collected in January and exposed to five subfreezing temperatures in a programmable temperature and humidity chamber. $\mathbf{L T}_{\mathbf{5 0}}$ was estimated by fitting relative electrolyte leakage and percentage of dead tissue against test temperature. For all tested species, triphenyltetrazolium chloride (TTC) staining of the pith was weak and the cambium TTCLT $_{50}$ was lower than the extreme minimum temperature $\left(-37^{\circ} \mathrm{C}\right)$ recorded in the region. The cambium TTCLT $_{50}$ and the SD were lower than that for the phloem and xylem. The phloem TTCLT ${ }_{50}$ was lower than the xylem TTCLT $_{50}$, and the two sDs were

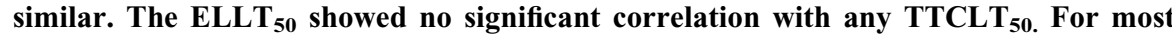
species, the ELLT $_{50}$ was higher than the cambium and phloem TTCLT T0 $_{50}$ and was not significant different with the xylem TTCLT $_{50}$. The ELLT To $_{50}$ showed higher SD than any

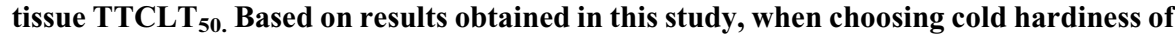
single stem tissue as an indicator for screening woody species, the xylem should be considered first, followed by the phloem; the cambium and pith were unsuitable. The cold hardiness estimated by ELLT $_{50}$ was more suitable as indicator for screening woody species than that of stem tissue in winter estimated by TTCLT T0. $_{\mathbf{5}}$
\end{abstract}

Cold hardiness is the ability of a plant or plant organ to tolerate freezing or survive freezing conditions (Fuchigami, 1996) without sustaining injury (Lindén et al., 2002; Weiser, 1970), which is a major determinant of plant species growth and distribution. Cold hardiness fluctuates between the seasons. During winter, plant species show increased tolerance to low temperatures with cold acclimation. The winter cold hardiness of a species is an important factor that ultimately affects species survival.

Cold hardiness evaluation is crucial for screening woody species in cold areas. Many methods have been used to quantify injury to woody stem pieces following laboratory freezing (Calkins and Swanson, 1990). The

Received for publication 14 Feb. 2020. Accepted for publication 21 May 2020.

Published online 25 June 2020.

This work was supported by Basic Scientific Research Fund of CAF (CAFYBB2017MA021), National Science and Technology Basic Resources Survey (2017FY10020404), and Central Public-interest Scientific Institution Basic Research Fund (CAFYBB2017SY003).

We appreciate Ping Ding Bao forestry farm, Tun Ken forestry farm, and Zhangiiakou Academy of Forestry for supporting collecting materials.

H.-Q.L. and Q.-H.L. are the corresponding authors. E-mail: Lihuiqing327@hotmail.com or riflitsing@ 163.com.

This is an open access article distributed under the CC BY-NC-ND license (https://creativecommons. org/licenses/by-nc-nd/4.0/). hydrogenases in the respiratory transport system (Sakai and Larcher, 1987). It measures the freezing injuries to metabolic activity (Lassheikki et al., 1991). The primary advantage of the latter method is that death in specific tissue can be detected, but visual classification of the staining intensity may be difficult (Purcell and Young, 1963) and is subjective (Nesbitt et al., 2002). According to Sakai (1955), freezing injury of twigs first appears as a brown ring at the peripheral layers of the xylem and pith tissue. Cold hardiness estimation of stem using the TTC test has been mainly focused on the phloem (Sharma and Graves, 2004; Soloklui et al., 2012) and xylem (Zhang et al., 2012). Although time-consuming, tissue browning is still generally used due to its reliability and ability to predict (Calkins and Swanson, 1990). In the present study, we use the M percentage in the CMYK color system (C: cyan; M: magenta; Y: yellow; K: black) using Adobe Photoshop (CS2) software (Adobe, San Jose, CA) to estimate objectively and quantitatively the staining intensity of stem pieces. This approach overcomes the aforementioned disadvantages and enables staining assessment more easily and precisely.

No single method is reliable for all materials (Calkins and Swanson, 1990). The objectives of this study were 1) to compare cold hardiness of the cambium, phloem, xylem, and pith for woody species by TTC staining and TTCLT $_{50}$; and 2) to compare cold hardiness estimations of woody species by

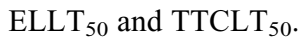

$\mathrm{LT}_{50}$ is most commonly used in measuring cold hardiness (Lindén et al., 2002). Among hardiness evaluation techniques, electrolyte leakage (EL) test and color reaction tests, such as TTC test, are widely used (Palonen and Buszard, 1997). EL test is based on the principle that damage to cell membranes results in enhanced leakage of electrolytes (mainly $\mathrm{K}^{+}$) from the cell (Lindén, 2002; Pukacki and Pukacka, 1987) and increases electrical conductivity (EC). $\mathrm{LT}_{50}$ estimated using the EL test $\left(\mathrm{ELLT}_{50}\right)$ means the temperature results in $50 \%$ increase in EL. Cell membranes are believed to be the primary sites of injury caused by stressful environmental conditions such as freezing temperatures (Lyons et al., 1979). EL test is an indirect measurement of the integrity of cell membranes (Steffen et al., 1989). Relative EL (initial EC1/final EC2) estimates the degree of cell membrane injury (Nesbitt et al., 2002), where EC1 is EC after freezing exposure and EC2 is EC after total disruption of cell membranes. A disadvantage of the EL test is that leakage among different tissues is not distinguished (Calkins and Swanson, 1990). The TTC test is based on the principle that living plant tissue can reduce TTC in the mitochondria to produce red formazan, whereas dead tissue cannot (Nesbitt et al., 2002). $\mathrm{LT}_{50}$ estimated with TTC test $\left(\mathrm{TTCLT}_{50}\right)$ means the temperature that results in 50\% decrease in TTC reduction, $50 \%$ red formazan, and $50 \%$ no staining. TTC reduction reflects the activities of some de-

\section{Materials and Methods}

Study area. The Bashang region of China is a transitional zone between the North China Plain and Inner Mongolian Plateau, and is a typical agricultural-pastoral plateau ecotone. The vegetation is dominated by semiarid grassland. Woody plants play an important environment protection function. The southern part of the region is an agricultural area and the northern part comprises grassland. Elevation ranges from 1000 to $1700 \mathrm{~m}$ and is typically higher (1400 $1700 \mathrm{~m}$ ) in the north. The winter is cold with the average monthly temperature is below $0{ }^{\circ} \mathrm{C}$ for 5 months. The 30 -year extreme minimum temperature in the region is $-37^{\circ} \mathrm{C}$, the minimum temperature in January (the coldest month) in most years is $-30{ }^{\circ} \mathrm{C}$, and the 30-year mean annual minimum temperature is $-22^{\circ} \mathrm{C}$. The average wind speed is $4.9 \mathrm{~m} \cdot \mathrm{s}^{-1}$ for the entire year and the highest wind speed recorded is $27 \mathrm{~m} \cdot \mathrm{s}^{-1}$. Low temperature poses a severe challenge to woody species survival in winter.

Plant material. Woody plant species were sampled from the Ping Ding Bao forestry farm (lat. $41^{\circ} 40^{\prime} \mathrm{N}$, long. $115^{\circ} 40^{\prime} \mathrm{E}, 1410 \mathrm{~m}$ ) and the Tun Ken forestry farm (lat. $41^{\circ} 54^{\prime} \mathrm{N}$, long. $\left.114^{\circ} 47^{\prime} \mathrm{E}, 1450 \mathrm{~m}\right)$ in the Bashang region of China. In total, 26 species belonging to 11 families were sampled, comprising 5 evergreen conifer species and 21 deciduous broadleaf species (Table 1). Using individual 
Table 1. Cold hardiness evaluation of 26 woody species by estimation of ELLT ${ }_{50}$ and TTCLT $_{50}$.

\begin{tabular}{|c|c|c|c|c|c|c|c|c|c|c|c|c|}
\hline \multirow[b]{2}{*}{ Species } & \multicolumn{3}{|c|}{ ELLT $_{50}$} & \multicolumn{3}{|c|}{${\text { Cambium } \text { TTCLT }_{50}}$} & \multicolumn{3}{|c|}{${\text { Phloem } \text { TTCLT }_{50}}$} & \multicolumn{3}{|c|}{ Xylem TTCLT $_{50}$} \\
\hline & $\mathrm{LT}_{50}$ & R-Square & Grade & $\mathrm{LT}_{50}$ & R-Square & Grade & $\mathrm{LT}_{50}$ & R-Square & Grade & $\mathrm{LT}_{50}$ & R-Square & Grade \\
\hline Pinus sylvestris & -64 & 0.94 & I & -68 & 0.84 & I & -57 & 0.76 & I & -25 & 0.68 & III \\
\hline Picea asperata & -54 & 0.98 & I & -60 & 0.83 & I & -50 & 0.95 & I & -32 & 0.90 & II \\
\hline Armeniaca sibirica & -46 & 0.93 & I & -55 & 0.93 & I & -47 & 0.91 & I & -31 & 0.92 & II \\
\hline Caragana korshinskii & -41 & 0.94 & I & -37 & 0.98 & I & -25 & 0.96 & III & -21 & 0.81 & IV \\
\hline Populus gansuensis & -41 & 0.94 & I & -62 & 0.82 & I & -45 & 0.75 & I & -30 & 0.66 & II \\
\hline Rubus corchorifolius & -38 & 0.93 & I & -59 & 0.91 & I & -46 & 0.84 & I & -41 & 0.83 & $\mathrm{I}$ \\
\hline Rosa davurica & -37 & 0.95 & $\mathrm{I}$ & -59 & 0.86 & I & -55 & 0.86 & I & -32 & 0.88 & II \\
\hline Populus simonii & -36 & 0.92 & II & -59 & 0.83 & I & -52 & 0.79 & I & -41 & 0.64 & $\mathrm{I}$ \\
\hline Populus $\times$ beijingensis & -35 & 0.95 & II & -54 & 0.67 & I & -42 & 0.77 & I & -39 & 0.72 & $\mathrm{I}$ \\
\hline Larix gmelinii & -34 & 0.97 & II & -63 & 0.88 & I & -55 & 0.82 & I & -24 & 0.79 & III \\
\hline Populus lasiocarpa & -34 & 0.98 & II & -57 & 0.85 & I & -42 & 0.82 & I & -34 & 0.61 & II \\
\hline Sabina vulgaris & -34 & 0.96 & II & -54 & 0.72 & I & -33 & 0.63 & II & -27 & 0.77 & III \\
\hline Populus alba var. pyramidalis & -33 & 0.95 & II & -60 & 0.91 & I & -48 & 0.80 & $\mathrm{I}$ & -40 & 0.92 & $\mathrm{I}$ \\
\hline Syringa oblata & -32 & 0.91 & II & -58 & 0.74 & I & -39 & 0.65 & I & -29 & 0.64 & III \\
\hline Swida alba & -30 & 0.92 & II & -57 & 0.88 & I & -45 & 0.81 & $\mathrm{I}$ & -37 & 0.91 & $\mathrm{I}$ \\
\hline Acer negundo & -29 & 0.97 & III & -53 & 0.90 & I & -34 & 0.86 & II & -16 & 0.77 & IV \\
\hline Populus alba & -29 & 0.91 & III & -55 & 0.86 & I & -53 & 0.78 & $\mathrm{I}$ & -49 & 0.80 & $\mathrm{I}$ \\
\hline Betula platyphylla & -28 & 0.96 & III & -61 & 0.95 & I & -47 & 0.84 & I & -38 & 0.62 & $\mathrm{I}$ \\
\hline Amygdalus triloba & -27 & 0.95 & III & -62 & 0.77 & I & -44 & 0.63 & I & -28 & 0.94 & III \\
\hline Populus alba $\times P$. glandulosa & -25 & 0.93 & III & -63 & 0.90 & I & -50 & 0.72 & I & -30 & 0.81 & II \\
\hline Ulmus pumila & -25 & 0.95 & III & -56 & 0.88 & I & -47 & 0.84 & $\mathrm{I}$ & -28 & 0.73 & III \\
\hline Prunus cerasifera & -24 & 0.96 & III & -57 & 0.79 & I & -47 & 0.83 & $\mathrm{I}$ & -29 & 0.80 & III \\
\hline Salix matsudana & -21 & 0.94 & IV & -53 & 0.84 & I & -29 & 0.82 & III & -27 & 0.73 & III \\
\hline Salix limprichtii & -20 & 0.94 & IV & -56 & 0.82 & I & -51 & 0.75 & I & -36 & 0.77 & II \\
\hline Hippophae rhamnoides & -17 & 0.98 & IV & -52 & 0.88 & I & -44 & 0.70 & $\mathrm{I}$ & -29 & 0.71 & III \\
\hline Juniperus rigida & -16 & 0.95 & IV & -53 & 0.91 & $\mathrm{I}$ & -45 & 0.90 & $\mathrm{I}$ & -27 & 0.91 & III \\
\hline
\end{tabular}

$\mathrm{LT}_{50}=50 \%$ lethal temperature $\left({ }^{\circ} \mathrm{C}\right) ; \mathrm{ELLT}_{50}=\mathrm{LT}_{50}$ estimated using electrolyte leakage test; $\mathrm{TTCLT}_{50}=\mathrm{LT}_{50}$ estimated using triphenyltetrazolium chloride test;

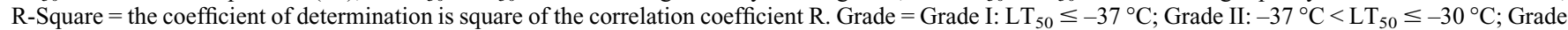
III: $-30{ }^{\circ} \mathrm{C}<\mathrm{LT}_{50} \leq-22{ }^{\circ} \mathrm{C}$; Grade IV: $-22{ }^{\circ} \mathrm{C}<\mathrm{LT}_{50}$.

plant parts to evaluate cold hardiness is the usual method in cold hardiness tests (Hoffman et al., 2010; Lisek, 2012). Thirty 1-year-old shoots ( $30-40 \mathrm{~cm}$ long) from the upper portion of the juvenile stage of each species were randomly collected in January. Most of the plants sampled were 6 to 7 years old. The cut wound was sealed with paraffin, and then the sampled shoots were stored in plastic bags at $0{ }^{\circ} \mathrm{C}$ in a cold room until the freezing test (all freezing tests were finished in less than 1 month).

Freezing procedure. The sampled shoots were transferred to a laboratory from the $0{ }^{\circ} \mathrm{C}$ cold room. For each species, the samples were divided into six sets: five sets were used for freezing tests and one set as nonfrozen control. Each set had five shoots.

Ice nucleation is considered crucial to ensure the accuracy of freezing tests (Workmaster et al., 1999). Each shoot for the freezing tests was rinsed with water, wrapped in moist cheese cloth and enclosed in aluminum foil (Ndlovu, 2015), placed in plastic bags, and transferred to a programmable temperature and humidity chamber (UK-80G; Qin Zhuo Environmental Equipment Company, Dongguan, China). The initial temperature was $-2{ }^{\circ} \mathrm{C}$. Materials were kept at $-2{ }^{\circ} \mathrm{C}$ for $24 \mathrm{~h}$ to equilibrate and ensure freezing. The cooling rate was -2 ${ }^{\circ} \mathrm{C} \cdot \mathrm{h}^{-1}$. This rate provides adequate time for intracellular water to migrate to freezing sites (Bigras and Colombo, 2001). The test temperature $\left(-15,-25,-35,-45\right.$, and $\left.-55^{\circ} \mathrm{C}\right)$ was maintained for $6 \mathrm{~h}$. The warming rate was 2 ${ }^{\circ} \mathrm{C} \cdot \mathrm{h}^{-1}$ and the final temperature was $4{ }^{\circ} \mathrm{C}$. After thawing for $12 \mathrm{~h}$ at the final temperature, the shoots were transferred to room temperature in a black bag for $\approx 12 \mathrm{~h}$ until the materials were evaluated.

EL test. Shoots were rinsed with deionized water and dried with filter paper; 0.2- to 0.5 -cm-long sections were cut from the apical, middle, and basal parts of each shoot. One gram was weighed. The number of replicates was five. Samples were immersed in $15 \mathrm{~mL}$ deionized water in a tube, incubated at room temperature $\left(22^{\circ} \mathrm{C}\right)$ for $11 \mathrm{~h}$, then shaken for $1 \mathrm{~h}$ at $200 \mathrm{rpm}$ on a THZ-22 constant temperature oscillator (Pei Ying Experiment Equipment Corporation Ltd, Taicang, China), and kept at room temperature $\left(22^{\circ} \mathrm{C}\right)$ for $12 \mathrm{~h}$. EC1 was measured using a DDSJ-30A conductivity meter (Shanghai Precision and Scientific Instrument Corporation Ltd, Shanghai, China). Then the samples were killed in a boiling water bath for $20 \mathrm{~min}$, kept at room temperature $\left(22^{\circ} \mathrm{C}\right)$ for $11 \mathrm{~h}$, shaken for $1 \mathrm{~h}$, and then kept at room temperature $\left(22^{\circ} \mathrm{C}\right)$ for $12 \mathrm{~h}$, and finally EC2 was measured. Relative EL (Rt) was calculated as Rt $(\%)=(\mathrm{EC} 1 / \mathrm{EC} 2) \times 100$.

TTC test. One $1-\mathrm{cm}-$ long section was cut from the apical, middle, and basal parts of each shoot, and placed in a tube, to which 10 $\mathrm{mL}$ 0.5\% 2,3,5-triphenyltetrazolium chloride (TTC) was added. The number of replicates was five. Samples were incubated for $24 \mathrm{~h}$ in the dark at room temperature and photographed using a light microscope (Bx53; Olympus, Tokyo, Japan). Stained tissues were coded as living and nonstained tissues as dead. Staining intensity of the cambium, phloem, xylem, and pith was separately estimated by the photographs using Adobe Photoshop (CS2) software (Adobe PhotoshopWindow-Info-M). M (magenta) percentage in the CMYK color system indicates the percentage of living tissue.

Estimation of $L T_{50}$. The $\mathrm{LT}_{50}$ of individual species estimated using the EL test $\left(E L_{50}\right)$ was determined by plotting the relative electrolyte leakage against the test temperature. The $\mathrm{LT}_{50}$ estimated with the TTCLT $_{50}$ was determined by plotting the average percentage of dead tissue against the test temperature. Both curves followed the sigmoidal logistic function type 3 (Gai, 2000), estimated using OriginPro 9.1 software (OriginLab, Northampton, MA; www.originlab.com):

$$
\mathrm{Y}=\frac{K}{1+a e^{-b X}},
$$

where $Y$ is the relative EL and the percentage of dead tissue; $X$ is the absolute test temperature (i.e., a positive value, because the test temperatures are negative); $K$ is the potential maximum value of $Y$, which we considered to be $100 \%$; and parameters $a$ and $b$ were estimated after curve fitting until convergence was attained. The $\mathrm{LT}_{50}$ were calculated using the following formula:

$$
L T_{50}=-\frac{\ln a}{b}
$$

Grading of species. Based on the $\mathrm{LT}_{50}$ and the minimum temperature in January (the coldest month) in the Bashang region, we classified the sampled species into four grades: Grade I species, $\mathrm{LT}_{50} \leq-37{ }^{\circ} \mathrm{C}$ (lower than the extreme minimum temperature in the region); Grade II species, $-37^{\circ} \mathrm{C}<$ $\mathrm{LT}_{50} \leq-30{ }^{\circ} \mathrm{C}$ (between the extreme minimum temperature in the region and the minimum temperature recorded in most years); 
A

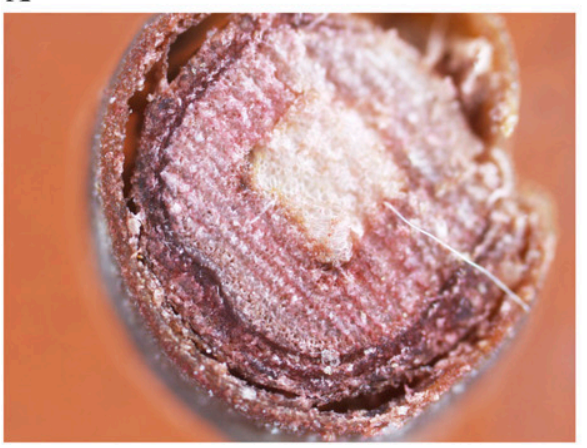

B

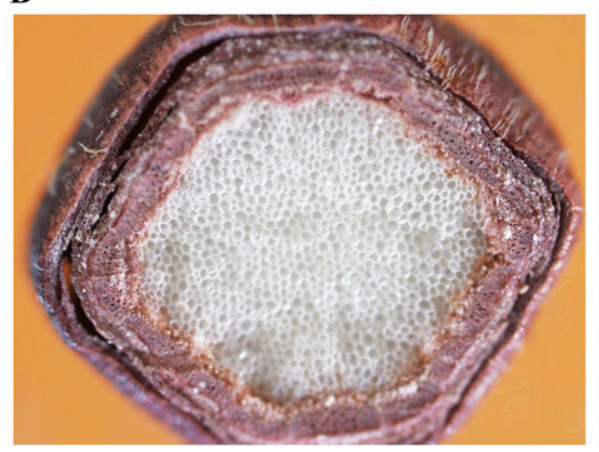

C

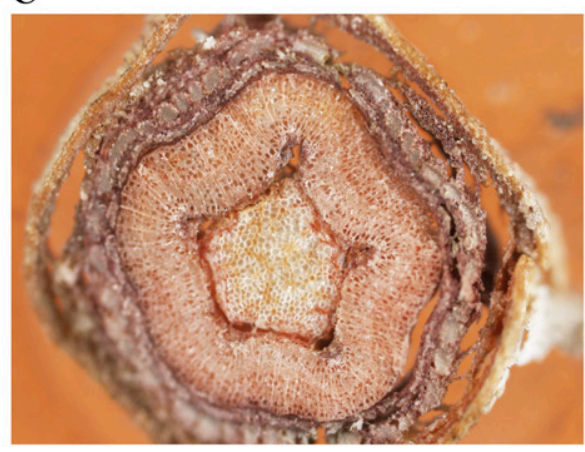

Fig. 1. TTC staining intensity estimation using M\% in the CMYK color system by Adobe Photoshop software on the stem photographs of 1 -year-old shoots of woody species exposed to subfreezing temperatures. (A) Poplar $84 \mathrm{~K}$ exposed to $-55^{\circ} \mathrm{C}$. Phloem: 67\%; Cambium: 70\%; Xylem: 51\%; Pith: 7\%. (B) Swida alba exposed to $-55^{\circ} \mathrm{C}$. Phloem: 61\%; Cambium: 77\%; Xylem: 51\%; Pith: 4\%. (C) Populus simonii exposed to -15 ' $\mathrm{C}$. Phloem: 68\%; Cambium: $74 \%$; Xylem: 49\%; Pith: 10\%. TTC = triphenyltetrazolium chloride. M\%= magenta percentage, which indicates the percentage of living tissue; CMYK = C: cyan; M: magenta; Y: yellow; K: black.

Table 2. Mann-Whitney test for the differences of special $50 \%$ lethal temperature $\left({ }^{\circ} \mathrm{C}\right)\left(\mathrm{LT}_{50}\right)$ for wood stem tissues.

\begin{tabular}{|c|c|c|c|c|}
\hline $\mathrm{F}(\mathrm{X})$ & $\mathrm{G}(\mathrm{Y})$ & $\mathrm{U}$ & Z & Asymp. Prob $>|\mathrm{U}|$ \\
\hline \multirow[t]{3}{*}{$\mathrm{ELLT}_{50}$} & Cambium TTCLT $_{50}$ & 640.5 & 5.53038 & $3.19531 \mathrm{E}-8$ \\
\hline & Phloem TTCLT $_{50}$ & 565.5 & 4.15783 & $3.21281 \mathrm{E}-5$ \\
\hline & Xylem TTCLT $_{50}$ & 328 & -0.17413 & $0.86176^{*}$ \\
\hline \multirow[t]{2}{*}{ Cambium TTCLT $_{50}$} & Phloem TTCLT $_{50}$ & 50.5 & -5.25884 & $1.44964 \mathrm{E}-7$ \\
\hline & Xylem TTCLT $_{50}$ & 6.5 & -6.06171 & $1.34685 \mathrm{E}-9$ \\
\hline Phloem TTCLT $_{50}$ & Xylem TTCLT $_{50}$ & 73 & -4.8447 & $1.26804 \mathrm{E}-6$ \\
\hline
\end{tabular}

$\mathrm{ELLT}_{50}=\mathrm{LT}_{50}$ estimated using electrolyte leakage test; $\mathrm{TTCLT}_{50}=\mathrm{LT}_{50}$ estimated using triphenyltetrazolium chloride test; $\mathrm{U}=$ the $\mathrm{U}$ statistic; $\mathrm{Z}=$ the

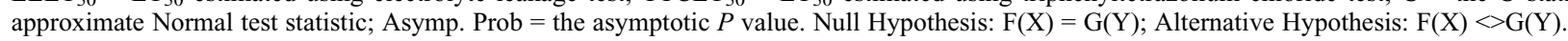

*Significant at the 0.05 level.

Table 3. Spearman correlation coefficients between ELLT $_{50}$ and TTCLT $_{50}$ for wood stem tissues.

\begin{tabular}{|c|c|c|c|c|}
\hline & $\mathrm{ELLT}_{50}$ & ${\text { Cambium } \text { TTCLT }_{50}}$ & ${\text { Phloem } \text { TTCLT }_{50}}$ & Xylem TTCLT $_{50}$ \\
\hline$\overline{E L L T}_{50}$ & 1 & 0.32343 & 0.17373 & 0.12159 \\
\hline$P$ value & - & 0.10702 & 0.39600 & 0.55405 \\
\hline Cambium TTCLT $_{50}$ & 0.32343 & 1 & $0.60870 *$ & 0.19708 \\
\hline$P$ value & 0.10702 & - & 0.00097 & 0.33455 \\
\hline Phloem TTCLT $_{50}$ & 0.17373 & 0.60870 & 1 & 0.34931 \\
\hline$P$ value & 0.39600 & 0.00097 & - & 0.08027 \\
\hline Xylem TTCLT $_{50}$ & 0.12159 & 0.19708 & 0.34931 & 1 \\
\hline$P$ value & 0.55405 & 0.33455 & 0.08027 & - \\
\hline
\end{tabular}

$\operatorname{ELLT}_{50}=50 \%$ lethal temperature estimated using electrolyte leakage test $\left({ }^{\circ} \mathrm{C}\right) ; \mathrm{TTCLT}_{50}=50 \%$ lethal temperature estimated using triphenyltetrazolium chloride test $\left({ }^{\circ} \mathrm{C}\right)$.

*Significant at the 0.05 level.

Table 4. Descriptive statistics for ELLT $_{50}$ and TTCLT $_{50}$

\begin{tabular}{|c|c|c|}
\hline & N Mean & Min Max \\
\hline$\overline{E L L T}_{50}$ & -33 & $10.81395-64-16$ \\
\hline Cambium TTCLT $_{5}$ & -57 & $\begin{array}{cccc}5.62481 & -68 & -37\end{array}$ \\
\hline Phloem TTCLT $_{50}$ & -45 & $7.86345-57-25$ \\
\hline Xylem TTCLT $_{50}$ & -31 & $7.13432-49-16$ \\
\hline $\begin{array}{l}\text { ELLT }_{50}=50 \% \text { leth } \\
\text { electrolyte leakage } \\
\text { temperature estim } \\
\text { lium chloride test } \\
\text { observations; SD } \\
\text { minimum; Max }=\mathrm{m}\end{array}$ & $\begin{array}{l}\text { al tempera } \\
\text { est }\left({ }^{\circ} \mathrm{C}\right) ; \mathrm{T} 7 \\
\text { ted usin } \\
\left.{ }^{\circ} \mathrm{C}\right) ; \mathrm{N}= \\
\text { standard } \\
\text { ximum. }\end{array}$ & $\begin{array}{l}\text { ture estimated using } \\
\mathrm{TCLT}_{50}=50 \% \text { lethal } \\
\mathrm{g} \text { triphenyltetrazo- } \\
\text { number of species } \\
\text { deviation; Min = }\end{array}$ \\
\hline
\end{tabular}

Grade III species, $-30{ }^{\circ} \mathrm{C}<\mathrm{LT}_{50} \leq-22{ }^{\circ} \mathrm{C}$ (between the minimum temperature recorded in most years and the 30-year mean annual minimum temperature); and Grade IV species, $-22^{\circ} \mathrm{C}<\mathrm{LT}_{50}$ (higher than the 30 -year mean annual minimum temperature).

Statistical analysis. Mann-Whitney test, descriptive statistics, and Spearman correla- tion analysis were performed using OriginPro 9.1 software.

\section{Results}

\section{Estimation of cold hardiness by TTC staining and TTCLT $_{\mathbf{5 0}}$}

Pith cold hardiness. For individual species, TTC staining intensity of stem was ranked as cambium $>$ phloem $>$ xylem $>$ pith (Fig. 1A-C). TTC staining of the pith was weak. The staining intensity of Swida alba exposed to $-55^{\circ} \mathrm{C}$ was close to zero (Fig. 1B), thus no $\mathrm{LT}_{50}$ estimate was calculated for the pith.

Cambium cold hardiness. Mann-Whitney test showed the cambium TTCLT ${ }_{50}$ was significantly different from the phloem and xylem TTCLT $_{50}$ (Table 2). The cambium TTCLT $_{50}$ was lower than the phloem and xylem TTCLT $_{50}$ (Table 1), thus the cambium showed higher cold hardiness than the phloem and xylem. The cambium TTCLT $_{50}$ showed a higher correlation with the phloem TTCLT $_{50}$ than that shown by the xylem TTCLT $_{50}$ (Table 3). The cambium TTCLT 50 showed a lower SD than the phloem and xylem TTCLT $_{50}$ (Table 4). For all tested species, the cambium TTCLT T0 $_{50}$ was lower than the extreme minimum temperature in the region $\left(-37^{\circ} \mathrm{C}\right)$. On the basis of the cambium TTCLT $_{50}$, all tested species were classified in Grade I. Pinus sylvestris could tolerate $-68^{\circ} \mathrm{C}$, whereas Caragana korshinskii could tolerate $-37^{\circ} \mathrm{C}$.

Phloem cold hardiness. Mann-Whitney test showed the phloem TTCLT ${ }_{50}$ was significantly different from the xylem TTCLT $_{50}$ (Table 2). The phloem TTCLT 50 was lower than that for the xylem (Table 1); therefore, the phloem cold hardiness was higher than of the xylem. The phloem TTCLT $_{50}$ showed a similar SD with the xylem TTCLT $_{50}$ (Table 4). Based on the phloem TTCLT $\mathrm{T}_{50}$, two species were classified in Grade II and two species belonged to Grade III, and for 22 
species the phloem TTCLT $_{50}$ was lower than the extreme minimum temperature $\left(-37^{\circ} \mathrm{C}\right)$. Pinus sylvestris could tolerate $-57{ }^{\circ} \mathrm{C}$, whereas $C$. korshinskii could tolerate $-25{ }^{\circ} \mathrm{C}$. Grade I species comprised Pinus sylvestris, Rosa davurica, Larix gmelinii, Populus alba, Populus simonii, Salix limprichtii, Populus alba $\times$ Populus glandulosa, Picea asperata, Populus alba var. pyramidalis, Armeniaca sibirica, Prunus cerasifera, Betula platyphylla, Ulmus pumila, Rubus corchorifolius, Swida alba, Populus gansuensis, Juniperus rigida, Hippophae rhamnoides, Amygdalus triloba, Populus $\times$ beijingensis, Populus lasiocarpa, and Syringa oblata.

Xylem cold hardiness. All studied species showed lower cold hardiness of the xylem, compared with the phloem (Table 1). $P$. sylvestris xylem tolerated $-25^{\circ} \mathrm{C}$, whereas the phloem tolerated $-57^{\circ} \mathrm{C}$. Based on the xylem cold hardiness, 7 species belonged to Grade I, 7 species were classified in Grade II, 10 species belonged to Grade III, and 2 species were categorized as Grade IV. Grade I species consisted of $P$. alba, $R$. corchorifolius, $P$. simonii, $P$. alba var. pyramidalis, Populus $\times$ beijingensis, B. platyphylla, and $S$. alba, of which four species belonged to the genus Populus.

Cold hardiness estimation by TTC and TTCLT $_{50}$ for 26 woody species revealed that the cambium showed the highest cold hardiness (Table 1) and the lowest SD (Table 4). The phloem showed higher cold hardiness than the xylem and similar SD with the xylem (Table 4).

\section{Estimation of cold hardiness by ELLT Fo $_{\mathbf{5 0}}$}

Mann-Whitney test on the studied species showed the ELLT 50 was significantly different from the cambium and phloem TTCLT $_{50}$ (Table 2). The ELLT ${ }_{50}$ also showed no significant correlation with any TTCLT $_{50}$, including the cambium TTCLT 50 , the phloem TTCLT $_{50}$, and the xylem TTCLT ${ }_{50}$ (Table 3 ). That meant the relationship between the

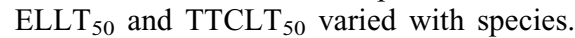
For most species, the ELLT ${ }_{50}$ was higher than the cambium and phloem TTCLT $_{50}$ (Table 1). That meant the species cold hardiness estimated by ELLT $_{50}$ was generally lower than the cold hardiness of cambium and phloem estimated by TTCLT ${ }_{50}$. Descriptive statistics showed mean value of the ELLT $_{50}$ was close to that of the xylem TTCLT $_{50}$ (Table 4). Mann-Whitney test showed there was no significant difference

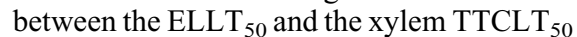
(Table 2), but for some individual species like Pinus sylvestris, there was still a big difference between the $\mathrm{LT}_{50}$ values estimated by these two methods. That meant the cold hardiness estimated by ELLT $_{50}$ was generally not significantly different from that of the xylem estimated by TTCLT T0 $_{50}$.

The cold hardiness of the test species estimated by ELLT $_{50}$ varied significantly (Table 1) and showed the highest SD (Table 4). P. sylvestris tolerated $-64{ }^{\circ} \mathrm{C}$, whereas $J$. rigida was tolerant of only
$-16{ }^{\circ}$ C. P. sylvestris, $P$. asperata, A. sibirica, $P$. gansuensis, $C$. korshinskii, $R$. corchorifolius, and $R$. davurica were tolerant of much lower temperatures than the extreme minimum temperature $\left(-37^{\circ} \mathrm{C}\right)$ in the region. In particular, $P$. sylvestris and $P$. asperata were tolerant of temperatures lower than $-50{ }^{\circ} \mathrm{C}$.

\section{Discussion}

Evaluation of cold hardiness estimated by TTCLT $_{50}$. Standard deviations (Table 4) showed the variation of cold hardiness among different species. Low SD means small variation of cold hardiness among different species. Indicator with low SD cannot screen species well. Tissue with a low cold hardiness is more sensitive to freezing damage than a tissue with greater cold hardiness. From the present results, when choosing a single stem tissue as an indicator for screening woody species, the xylem should be considered first followed by the phloem. The cambium and pith were not suitable. The cambium is critical to plant survival (Pellett and Heleba, 1998), but the TTCLT 50 for all species was lower than the extreme minimum temperature $\left(-37^{\circ} \mathrm{C}\right)$, and the SD was lowest among the different tissues (Table 4), thus the cambium was not suitable as an indicator of cold hardiness for screening species. TTC staining of the pith was weak and thus the pith was also unsuitable for screening species. The TTC staining and special $\mathrm{LT}_{50}$ was also affected by freezing and TTC test procedure such as time length of freezing test temperature. Some authors provided a similar recommendation to use the xylem as an indicator of cold hardiness using the TTC method (Nesbitt et al., 2002; Pellett and Heleba, 1998); however, the recommendation was based on discoloration of 1-year-old stems of deciduous plants, because the phloem and cambium were difficult to discern with the naked eye or at low magnification and the xylem was easier to observe. Some authors also found the xylem possesses less cold hardiness than the phloem in winter (Einhorn et al., 2011; Parker, 1962).

Estimation of cold hardiness by ELLT $T_{50}$ and TTCLT 50 . The ELLT ${ }_{50}$ showed a higher SD than any tissue TTCLT $_{50}$ (Table 4). That meant the cold hardiness of test species estimated by ELLT $_{50}$ showed higher variation than that estimated by TTCLT $_{50}$. $E L_{L} T_{50}$ was suitable for screening species as cold hardiness indicator. In field practice experience, $E_{L L T}$ fit the growing state of conifer species well. The cold hardiness estimated by ELLT $_{50}$ showed P. sylvestris and $P$. asperata could tolerate much lower temperature than $J$. rigida (Table 1 ), and the former two species grow much better than the latter species that live in similar environmental conditions in the Bashang region.

ELLT $_{50}$ represents the lethal temperature at which $50 \%$ of electrolyte leakage occurs (Fiorino and Mancuso, 2000), and TTCLT 50 means the lethal temperature at which $50 \%$ of tissues are damaged (Fiorino and Mancuso, 2000) by visual assessment of staining in the targeted tissue. ELLT $_{50}$ is associated with erratic function or total dysfunction of cell membranes after freezing, whereas TTCLT $_{50}$ is associated with the ability of tissue to respire after exposure to cold stress (Soloklui et al., 2012). Steffen et al. (1989) found the function of cell membranes is altered earlier than is the respiratory function of tissue under freezing stress in studying two potato species. Initial alteration of cell membranes is reversible (Palta et al., 1982). This study showed the freezing tolerance of cell membranes was generally lower than that of the respiratory systems in the cambium and phloem. The freezing tolerance measured by $\mathrm{EL}$ and by function of respiratory systems in the xylem generally showed no significant difference.

\section{Conclusions}

This study mainly showed the cold hardiness differences of woody species evaluated by ELLT $_{50}$ and TTCLT TO $_{50}$. Based on results obtained in this study, when choosing cold hardiness of single stem tissue as an indicator for screening woody species, we recommended considering the xylem first, followed by the phloem. The cambium and pith were not suitable. Using $M$ percentage in the CMYK color system by Adobe Photoshop software could improve the accuracy of TTC staining estimation. The cold hardiness estimated by ELLT $_{50}$ was more suitable as an indicator for screening woody species than that of stem tissue in winter estimated by the TTCLT $_{50}$.

\section{Literature Cited}

Bigras, F.J. and S.J. Colombo. 2001. Conifer cold hardiness (vol. 1). Springer Science and Business Media, Dordrecht.

Calkins, J.B. and B.T. Swanson. 1990. The distinction between living and dead plant tissueviability tests in cold hardiness research. Cryobiology 27(2):194-211.

Einhorn, T.C., J. Turner, D. Gibeaut, and J.D. Postman. 2011. Characterization of cold hardiness in quince: Potential pear rootstock candidates for northern pear production regions. Acta Hort. 909:137-143.

Fiorino, P. and S. Mancuso. 2000. Differential thermal analysis, supercooling and cell viability in organs of Olea europaea at subzero temperatures. Adv. Hort. Sci. 14:23-27.

Fuchigami, L.H. 1996. Cold hardiness, p. 146. In: F.B. Salisbury (ed.). Units, symbols, and terminology for plant physiology (a reference for presentation of research results in the plant sciences). Oxford University Press, New York

Gai, J.Y. 2000. Experimental statistics methods. Chinese Agriculture Publishing Company, Beijing.

Hoffman, L., M. DaCosta, J.S. Ebdon, and E. Watkins. 2010. Physiological changes during cold acclimation of perennial ryegrass accessions differing in freeze tolerance. Crop Sci. 50(3):1037-1047.

Lassheikki, M., P. Puttonen, and P.K. Räsänen. 1991. Planting performance potential of Pinus sylvestris seedlings as evaluated by root growth capacity and triphenyl tetrazolium chloride reduction methods. Scand. J. For. Res. 6:91104. 
Lindén, L. 2002. Measuring cold hardiness in woody plants. Univ. of Helsinki, Helsinki, PhD Diss. < https://mafiadoc.com>.

Lindén, L., P. Palonen, and T. Hytönen. 2002. Evaluation of three methods to assess winter hardiness of strawberry genotypes. J. Hort. Sci. Biotechnol. 77(5):580-588.

Lisek, J. 2012. Winter frost injury of buds on oneyear-old grapevine shoots of Vitis vinifera cultivars and interspecific hybrids in Poland. Folia Hort. 24(1):97-103.

Lyons, J.M., J.K. Raison, and P.L. Steponkus. 1979. The plant membrane in response to low temperature: An overview, p. 1-24. In: J.M. Lyons, D. Graham, and J.K. Raison (eds.). Low temperature stress in crop plants: The role of the membrane. Academic Press, New York.

Ndlovu, F. 2015. Evaluation of Spring Frost Control Methods and an Assessment of Cold Hardiness in Cranberry (Vaccinium macrocarporn Ait.). Univ. of Massachusetts, Amherst, PhD Diss. 533. <https://scholarworks.umass.edu/ dissertations_2/533>.

Nesbitt, M.L., R.C. Ebel, D. Findley, B. Wilkins, F. Woods, and D. Himelrick. 2002. Assays to assess freeze injury of Satsuma mandarin. HortScience 37:871-877.
Palonen, P. and D. Buszard. 1997. Current state of cold hardiness research on fruit crops. Can. J. Plant Sci. 77(3):399-420.

Palta, J.P., K.G. Jensen, and P.H. Li. 1982. Cell membrane alterations following a slow freezethaw cycle: Ion leakage, injury and recovery, $\mathrm{p}$. 221-242. In: P.H. Li and A. Sakai (eds.). Plant cold hardiness and freezing stress. Academic Press, New York.

Parker, J. 1962. Seasonal changes in cold resistance and free sugars of some hardwood tree barks. For. Sci. 8(3):255-262.

Pellett, N.E. and D.A. Heleba. 1998. Comparing callus growth with discoloration and electrical conductivity as measures of stem injury after freezing woody plants. J. Amer. Soc. Hort. Sci. 123(5):826-831.

Pukacki, P. and S. Pukacka. 1987. Freezing stress and membrane injury of Norway spruce (Picea abies) tissues. Physiol. Plant. 69(1):156-160.

Purcell, A.E. and R.H. Young. 1963. The use of tetrazolium in assessing freeze damage in Citrus trees. Proc. Amer. Soc. Hort. Sci. 83:352358.

Sakai, A.A method for testing the survival of the twig1955. Teion Kagaku, Seibutsu-hen (Low Temp. Sci., Ser. B: Biol. Sci.) 13:43-50.
Sakai, A. and W. Larcher. 1987. Frost survival of plants: Responses and adaptation to freezing stress. Springer-Verlag, Berlin.

Sharma, J. and W.R. Graves. 2004. Midwinter cold hardiness of Leitneria floridana from three provenances. J. Environ. Hort. 22(2):88-92.

Soloklui, A.A.G., A. Ershadi, and E. Fallahi. 2012. Evaluation of cold hardiness in seven Iranian commercial pomegranate (Punica granatum L.) cultivars. HortScience 47:1821-1825.

Steffen, K.L., R. Arora, and J.P. Palta. 1989. Relative sensitivity of photosynthesis and respiration to freeze-thaw stress in herbaceous species: Importance of realistic freeze-thaw protocols. Plant Physiol. 89(4):1372-1379.

Weiser, C.J. 1970. Cold resistance and injury in woody plants: Knowledge of hardy plant adaptations to freezing stress may help us to reduce winter damage. Science 169(3952):1269-1278.

Workmaster, B.A.A., J.P. Palta, and M. Wisniewski. 1999. Ice nucleation and propagation in cranberry uprights and fruit using infrared video thermography. J. Amer. Soc. Hort. Sci. 124(6):619-625.

Zhang, J., X. Wu, R. Niu, Y. Liu, N. Liu, W. Xu, and Y. Wang. 2012. Cold-resistance evaluation in 25 wild grape species. Vitis 51(4):153-160. 